\title{
Heavy metals concentration in selected vegetables grown in Dohuk City, Kurdistan region, Iraq
}

\author{
R. O. H. Sulaivany ${ }^{1} \&$ H. A. M. Al-Mezori ${ }^{2}$ \\ ${ }^{1}$ Department of Horticulture, College of Agriculture, \\ University of Dohuk, Iraq \\ ${ }^{2}$ Department of Biology, College of Science, University of Dohuk, Iraq
}

\begin{abstract}
This research is conducted to evaluate the levels of some heavy metals (such as lead, cadmium, nickel, and copper) and their concentrations in water and in the most common vegetables (chard, celery, leek, onion and radish) which are cultivated in five common locations in Dohuk city farms, and irrigated with wastewater. The study in the concentration of heavy metals found in water used for vegetable irrigation indicates that the water of the College of Agriculture is not contaminated; while the water from all the other locations was highly contaminated. The results from the vegetable content analysis of heavy metals indicate that chard plants accumulate more lead and cadmium, while radish plants accumulate less. Concentrations of lead $(\mathrm{Pb})$ and cadmium $(\mathrm{Cd})$ obtained from vegetables grown in all the studied locations exceeds significantly in concentrations when obtained from the College of Agriculture location. Their relatively high concentration exceeds maximum permissible levels (MPL) in vegetables $(\mathrm{WHO})$. The mean $(\mathrm{Pb})$ concentrations of chard, celery, leek, onion, and radish plants were $4.188 ; 4.0 ; 3.719 ; 3.663$; and $2.66 \mathrm{mg} . \mathrm{kg}^{-1} \mathrm{~d}$. wt respectively, while the mean $\mathrm{Cd}$ concentration in chard, celery, leek, onion, and radish plants were $0.422,0.37,0.355,0.346$, and $0.228 \mathrm{mg} . \mathrm{kg}^{-1} \mathrm{~d}$. wt respectively. Among locations, the Dilan Hall appeared to be more contaminated, whereas the College of Agriculture location is less contaminated. The concentration of both nickel $(\mathrm{Ni})$ and copper $(\mathrm{Cu})$ in all studied vegetables and in all locations didn't exceed (MPL) in vegetables. Mean Ni concentrations in chard, celery, leek, onion, and radish plants were $3.73 ; 4.07 ; 3.45 ; 3.66$; and $3.25 \mathrm{mg}$. kg ${ }^{-1} \mathrm{~d}$. wt, while Mean $\mathrm{Cu}$ concentrations were $14.4 ; 14.0 ; 12.8 ; 10.15$; and $7.96 \mathrm{mg} . \mathrm{kg}^{-1} \mathrm{~d}$. wt, respectively.
\end{abstract}

Keywords: heavy metals, vegetables, wastewater, contamination, chemicals. 


\section{Introduction}

Vegetables constitute an important part of the human diet, because they contain carbohydrates and proteins, as well as vitamins, minerals and trace elements. Recently their consumption has been increased gradually, particularly among the urban community due to the awareness of the food value of vegetables [21]. Various types of vegetables are often grown on the embankment along the branches of the two rivulets within Dohuk city. These farms are irrigated with wastewater from the domestic activity of Dohuk residents which is contaminated with various pollutants, among which are the heavy metals.

Shortage of clean water for irrigation has given rise to the use of alternative sources, such as wastewater which is removed from residential and commercial establishments. Wastewater is contaminated with different heavy metals and toxic chemicals; therefore, the irrigation of vegetables with such water may lead to "Bioaccumulation" of heavy metals in these vegetables. This may create serious problems for the safe utilization of agricultural products, since heavy metals can be absorbed and accumulated by plants to a level that affects human health [20].

In Dohuk city, the availability of renewable water resources for irrigation is poor and is worsening over time. Thus, farmers are obliged to use wastewater, without any pretreatment, for irrigation of their fields to produce vegetables. This wastewater is heavily contaminated with heavy metals [22].

To our knowledge, no research has been published on toxic levels of some heavy metals in the vegetables of Dohuk city. As large amounts of these vegetables are consumed yearly we found that it is necessary to conduct our research on the vegetables to determine the concentration of some toxic heavy metals in vegetables from different areas of Dohuk city which are irrigated with wastewater.

\section{Materials and methods}

Various vegetables such as chard (Beta Vulgaris L. Var. Cicla), celery (Apium graveolens L.), Leek (Allium porrum L.), onion (Allium cepa L.) and radish (Raphanus sativus L.) were sampled from Dohuk city farms and screened for heavy metal (Lead, Cadmium, Nickel and Copper) concentration levels.

\subsection{The studied area}

The studied area is around the rivulet of Dohuk city, which passes through the city from east to west. The main source of water for this rivulet is from Dohuk impoundment and the municipality of the residential areas. The wastewater from the city quarters accumulated in this rivulet, which is the source for irrigation of different farms that cultivate fruit plants and vegetables. The vegetable samples were taken from five locations; Baroshke (Baro.), Azadi Hospital (Azadi H.), Shele, Dilan Hall and the Agriculture college (Agri. College) farms. 


\subsection{Water samples collection}

Samples of sewage water were taken monthly from the upstream to down stream of Dohuk rivulet from January 2004 till December 2004 from the five chosen locations inside Dohuk city; Baro., Azadi H., Shele, and Dilan Hall. At the same time samples from Agri. College location were taken as control. Three replicate of water samples were taken with 5 minutes interval in a polyethylene bottles, pre-washed with nitric acid solution (1:1) and after collection, samples were acidified by adding drops of nitric acid to a $\mathrm{pH}$ below (2) to minimize the precipitation and adsorption on container walls.

Water samples were digested [5], ut 100-ml of water brought to a $125 \mathrm{ml}$ beaker, $5 \mathrm{ml}$ conc. $\mathrm{HNO}_{3}$ was added to the samples and boiled on a hot plate to the lowest possible volume. The heating continued and adding of conc. $\mathrm{HNO}_{3}$ until digestion was complete as shown by a light-colored, clear solution. The digested samples were completed with deionizer water to $25-\mathrm{ml}$ in volumetric flask.

\subsection{Vegetable samples collection}

Fresh samples of vegetables were collected from the studied locations three times per year (spring, summer and autumn). Only the edible part of each vegetable was used for analytical purposes.

Three replicates of vegetables from different farms were collected into polyethylene bags. Removal of soil from samples were performed by shaking under tap water, then washed with distilled water, and finally rinsed with deionized water, dried in an oven at $70^{\circ} \mathrm{C}$ for 48 hours, and then ground to powder with a hand mill for heavy metal analysis.

\subsection{Digestion of vegetable samples}

After homogenization of the bulk sample of each farm, $(0.5 \mathrm{gm})$ vegetable samples were transferred to a $100 \mathrm{ml}$ conical flask and $10 \mathrm{ml}$ of acid mixture (nitric acid: perchloric acid) at the ratio (9:4) was added [23]. The flasks were placed on a hotplate with a low temperature in the digestion chamber, and then the cap of the flask was opened to release the $\mathrm{NO}_{2}$ fumes. Digestion continued until the liquid became colorless. The contents were further evaporated until the volume was reduced to about 3 to $5 \mathrm{ml}$, but not to dryness. Finally the digested samples were diluted with distilled deionized water to the final volume $(50 \mathrm{ml})$ in a volumetric flask. The concentration of heavy metals was determined by atomic absorption spectrophotometer (AAS) (Pyeunicom, model SP9) equipped with a hollow-cathode lamp.

\subsection{Statistical analysis}

Randomized Complete Block Design (RBCD) was used for statistical analysis by using the Microsoft (STATGRAF Ver.4). Analysis of variance (ANOVA) and Duncan Multiple range tests were employed to examine the statistical 
significance of differences in the mean concentration of heavy metals among locations. A probable level of $\mathrm{P}<0.05$ was considered statistically significant.

\section{Results and discussion}

The concentration of heavy metals in wastewater used for vegetable irrigation in (Table 1) indicates that the water of Agri. College is not contaminated with $\mathrm{Pb}$ and $\mathrm{Cd}$, and only a very low concentration of $\mathrm{Ni}$ and $\mathrm{Cu}$ was detected, while the water of all other locations was highly contaminated. High concentration of all heavy metals observed in the wastewater of the rivulet in the Baro. location, this means that the main source of heavy metals in water is car maintains region present in Baro. region, and increased downstream. Therefore, the highest values were found in the Dilan Hall location which is situated in the lowest point of the rivulet. The lowest concentration of heavy metals was recorded in the Baro. location. The significant differences observed between heavy metals content in water of Agri. college location and water of different other locations of rivulet, this may be due to the fact that in the Agri. college location, the drinking water is the main source for irrigation, whereas the rivulet received highly contaminatedwastewater from residential activities. The concentration of all heavy metals in wastewater used for irrigation from Dohuk rivulet surpassed (MPL) in irrigation water in Europe and Russia, [7].

Table 1: Heavy metals concentration $\left(\mu \mathrm{g} . \mathrm{L}^{-1}\right)$ of wastewater used for Vegetables irrigation from different locations of Dohuk city.

\begin{tabular}{|l|c|c|c|c|}
\hline \multirow{2}{*}{ Locations } & \multicolumn{4}{|c|}{ Heavy metals } \\
\cline { 2 - 5 } & $\mathrm{Pb}$ & $\mathrm{Cd}$ & $\mathrm{Ni}$ & $\mathrm{Cu}$ \\
\hline \multirow{2}{*}{ Baro. } & $\mathrm{b}^{*}$ & $\mathrm{a}$ & $\mathrm{b}$ & $\mathrm{a}$ \\
& 280.95 & 71.46 & 271.11 & 279.00 \\
\hline \multirow{2}{*}{ Azadi Ho. } & $\mathrm{a}$ & $\mathrm{a}$ & $\mathrm{ab}$ & $\mathrm{a}$ \\
& 285.03 & 75.10 & 275.16 & 282.90 \\
\hline \multirow{2}{*}{ Shele } & $\mathrm{a}$ & $\mathrm{a}$ & $\mathrm{ab}$ & $\mathrm{a}$ \\
& 285.44 & 74.61 & 275.68 & 283.20 \\
\hline \multirow{2}{*}{ Dilan Hall } & $\mathrm{a}$ & $\mathrm{a}$ & $\mathrm{a}$ & $\mathrm{a}$ \\
& 287.12 & 75.69 & 277.75 & 284.50 \\
\hline \multirow{2}{*}{ Agri. College } & & & $\mathrm{c}$ & $\mathrm{b}$ \\
& $\mathrm{ND}$ & $\mathrm{ND}$ & 26.50 & 41.10 \\
\hline
\end{tabular}

*Means, with the same letters in each column are not significantly different at $5 \%$ level based on Duncan's Multiple Range Tests.

ND not detectable.

The concentrations of lead in different plant types, as shown in table 2 indicated that chard plants accumulate higher concentrations $\left(4.188 \mathrm{mg} . \mathrm{kg}^{-1} \mathrm{~d}\right.$. wt.) than all other tested plants, and radish plants were lower accumulators (2.266 mg. $\mathrm{kg}^{-1} \mathrm{~d}$. wt.). Among locations, vegetable plants taken from the Dilan Hall appeared to be more contaminated, while, the vegetables from the Agri. 
College location were less contaminated. This may be due to several factors, among them are the possibility of translocation of heavy metals from contaminated wastewater used for irrigation as indicated from finding table 1 and the distance of farms from the roadside, levels of soil contamination with lead, application of farm yard manure, sewage sludge, wastewater, and the part of the plant analyzed [17].

The concentration of $\mathrm{Pb}$ shows that the lowest content was found in chard plants from the Agri. College location (3.344 mg. $\mathrm{kg}^{-1} \mathrm{~d}$. wt.) which was significantly different from all other locations, while the highest $\mathrm{Pb}$ content (4.477 mg. $\mathrm{kg}^{-1} \mathrm{~d}$. wt.) was obtained from Azadi H. location.

These results were near to (3.4 mg. $\mathrm{kg}^{-1} \mathrm{~d}$. wt.), recorded by Voegborlo, [27] and higher than $1.49 \mathrm{mg} . \mathrm{kg}^{-1} \mathrm{~d}$. wt., observed by Itanna, [15].

The concentration of lead in the celery plants in table 2 indicates that the highest $\mathrm{Pb}$ content $\left(4.833 \mathrm{mg}\right.$. $\mathrm{kg}^{-1}$ d. wt.) was obtained from the Dilan Hall location which significantly differed from other locations, and the lowest content (3.78 mg. kg ${ }^{-1} \mathrm{~d}$. wt.) was found in the Agri. College location.

These results were near to the $\mathrm{Pb}$ content in celery plants $\left(5.1 \mathrm{mg} . \mathrm{kg}^{-1} \mathrm{~d} . \mathrm{wt}\right)$

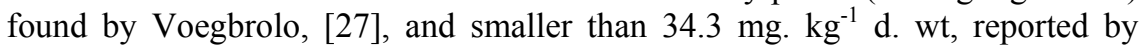
Czuba and Hutchinson, [9], but they were within the range of Al-Barewari, [3] study. It can be seen that the least $\mathrm{Pb}$ content in leek plants in table 2 was found in the Agri. College location, (3.355 mg. $\mathrm{kg}^{-1} \mathrm{~d}$. wt) which was significantly different from Dilan Hall and Azadi $\mathrm{H}$. locations and insignificant from the others, and the highest $\mathrm{Pb}$ content concentration $\left(4.533 \mathrm{mg}\right.$. $\mathrm{kg}^{-1} \mathrm{~d}$. wt) was obtained from leek plants grown in the Dilan Hall location, which was significantly different from all other locations. These results are more than 2.3 mg. $\mathrm{kg}^{-1} \mathrm{~d}$. wt, of $\mathrm{Pb}$ in leek plants recorded by Fytianos et al, [12], but smaller than $\left(229 \mathrm{mg} . \mathrm{kg}^{-1} \mathrm{~d}\right.$. wt $)$ in leek plants pointed out by Védry et al., [26].

Table 2: $\quad$ Lead content (mg. $\mathrm{kg}^{-1} \mathrm{~d}$. wt.) of plant types from different locations of Dohuk city.

\begin{tabular}{|l|c|c|c|c|c|}
\hline \multirow{2}{*}{ Locations } & \multicolumn{5}{|c|}{ Plant types } \\
\cline { 2 - 6 } & Chard & Celery & Leek & Onion & Radish \\
\hline \multirow{2}{*}{ Baro. } & $\mathrm{a}^{*}$ & $\mathrm{~d}$ & $\mathrm{bc}$ & $\mathrm{a}$ & $\mathrm{a}$ \\
& 4.400 & 3.422 & 3.622 & 4.583 & 2.633 \\
\hline \multirow{2}{*}{ Azadi H. } & $\mathrm{a}$ & $\mathrm{b}$ & $\mathrm{b}$ & $\mathrm{b}$ & $\mathrm{ab}$ \\
& 4.477 & 4.055 & 3.666 & 3.183 & 2.400 \\
\hline \multirow{2}{*}{ Shele } & $\mathrm{a}$ & $\mathrm{bc}$ & $\mathrm{bc}$ & $\mathrm{b}$ & $\mathrm{a}$ \\
& 4.266 & 3.900 & 3.422 & 3.350 & 2.433 \\
\hline \multirow{2}{*}{ Dilan Hall } & $\mathrm{a}$ & $\mathrm{a}$ & $\mathrm{a}$ & $\mathrm{a}$ & $\mathrm{ab}$ \\
& 4.455 & 4.833 & 4.533 & 4.383 & 2.233 \\
\hline \multirow{2}{*}{ Agri. College } & $\mathrm{b}$ & $\mathrm{bc}$ & $\mathrm{c}$ & $\mathrm{c}$ & $\mathrm{c}$ \\
& 3.344 & 3.780 & 3.355 & 2.816 & 1.633 \\
\hline Mean & 4.188 & 4.00 & 3.719 & 3.663 & 2.266 \\
\hline
\end{tabular}

* Means with the same letters in each column are not significantly different at 5\% level based on Duncan's multiple range tests. 
The concentration of lead in onion plants in table 2 indicated that the highest concentration was found in the Baro. location $\left(4.583 \mathrm{mg} . \mathrm{kg}^{-1} \mathrm{~d}\right.$. wt) which was significantly different from all other locations except that of the Dilan Hall location, and the lowest concentration was recorded in the Agri. College location (2.816 mg. $\mathrm{kg}^{-1} \mathrm{~d}$. wt).

The lowest $\mathrm{Pb}$ content in the radish plants was seen in the Agri. College location (1.633 mg. kg-1 d. wt), and the highest concentration was found in Baro. location $(2.633 \mathrm{mg}$. kg-1 d. wt). The $\mathrm{Pb}$ content in the radish plants in this study was similar to the results of Adhikari et al., [1], but lower than (14.7 mg. $\mathrm{kg}-1 \mathrm{~d}$. wt), found by Ansari et al., [4].

The existence of high concentrations of heavy metals in the vegetables depends on the quality of water used for irrigation [22], soil contamination the technology of the growing and processing of given products [13]. The concentration of $\mathrm{Pb}, \mathrm{Cd}, \mathrm{Ni}$, and $\mathrm{Cu}$ in the plant material reflects the regional atmospheric deposition of those elements [18].

The concentration of $\mathrm{Pb}$ in the vegetables was recorded in order of chard plants $>$ celery plants $>$ leek plants $>$ onion plants $>$ radish.

The accumulation of $\mathrm{Pb}$ in the chard, celery, leek, onion, and radish which sampled from all locations was higher than the maximum permissible levels (MPL) of $0.3 \mathrm{mg} . \mathrm{kg}^{-1}$. d. wt. in the vegetables as stated by Food and Agriculture Organization (FAO)/ World Health Organization (WHO), [8].

The concentration of cadmium in different plant types in table 3 indicates that the highest $\mathrm{Cd}$ content in chard plants was in the Baro. location $\left(0.53 \mathrm{mg} . \mathrm{kg}^{-1} \mathrm{~d}\right.$. $\mathrm{wt}$ ), and the lowest concentration of $\mathrm{Cd}$ in chard plants was in the Agri. College location $\left(0.2 \mathrm{mg}\right.$. $\mathrm{kg}^{-1} \mathrm{~d}$. wt) which was significantly different from all other locations. Concentration of $\mathrm{Cd}$ in the chard plants of this study is near to $(0.6$ mg. $\mathrm{kg}^{-1} \mathrm{~d}$. wt), mentioned by Voegborlo, [27], and less than $\left(1.62 \mathrm{mg} . \mathrm{kg}^{-1} \mathrm{~d}\right.$. wt), reported by Mohamed et al., [16].

Concentration of $\mathrm{Cd}$ in celery plants in table 3 indicates that among the five locations, the lowest concentration was in the Agri. College location $(0.055 \mathrm{mg}$. $\mathrm{kg}^{-1} \mathrm{~d}$. wt) and the highest concentration was obtained from the Baro. location $\left(0.57 \mathrm{mg} . \mathrm{kg}^{-1} \mathrm{~d}\right.$. wt), which differed significantly from all other locations.

Leek plants sampled from the Agri. College location contained lower concentrations of $\mathrm{Cd}\left(0.212 \mathrm{mg}\right.$. $\mathrm{kg}^{-1} \mathrm{~d}$. wt), which differed significantly from other locations in this study except that of the Dilan Hall location which differed insignificantly. But the samples obtained from the Azadi H. location contained the highest concentrations of $\mathrm{Cd}\left(0.521 \mathrm{mg} . \mathrm{kg}^{-1} \mathrm{~d}\right.$. wt), which differs significantly from other locations except the Azadi. H. location which differed insignificantly. $\mathrm{Cd}$ content in the leek plants of this study was within the same

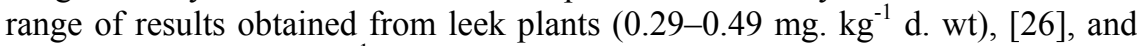
smaller than $3.94 \mathrm{mg}$. $\mathrm{kg}^{-1} \mathrm{~d}$. wt [19].

The lowest concentration of $\mathrm{Cd}$ content in the onion plants was observed in the Agri. College location $\left(0.135 \mathrm{mg} . \mathrm{kg}^{-1} \mathrm{~d}\right.$. wt $)$ which was significantly different from all other locations, this may be due to the fact that irrigation was done using tap water. The highest concentration $\left(0.533 \mathrm{mg} . \mathrm{kg}^{-1} \mathrm{~d}\right.$. wt $)$, was obtained from the Baro. location which was significantly different from the other 
locations except that of the Dilan Hall which differed insignificantly. This may be because of the presence of car repair shops which release large amounts of these heavy metals. Cd concentration in the onion plants of this study was higher than the results of Fahim et al., [11], and less than the results obtained by ElNaim et al., [10]. Concentration of $\mathrm{Cd}$ in the radish in table 3 shows the lowest level of $\mathrm{Cd}$ in the Agri. College location $\left(0.166 \mathrm{mg} . \mathrm{kg}^{-1} \mathrm{~d}\right.$. wt) which was significantly different from all other locations.

Table 3: Cadmium content (mg. $\mathrm{kg}^{-1} \mathrm{~d}$. wt.) of different plant types from different locations of Dohuk city.

\begin{tabular}{|l|c|r|r|r|r|}
\hline \multirow{2}{*}{ Locations } & \multicolumn{5}{|c|}{ Plant types } \\
\cline { 2 - 6 } & Chard & Celery & Leek & Onion & Radish \\
\hline \multirow{2}{*}{ Baro. } & $\mathrm{a}^{*}$ & $\mathrm{a}$ & $\mathrm{ab}$ & $\mathrm{a}$ & $\mathrm{a}$ \\
& 0.530 & 0.577 & 0.427 & 0.533 & 0.250 \\
\hline \multirow{2}{*}{ Azadi H. } & $\mathrm{ab}$ & $\mathrm{b}$ & $\mathrm{a}$ & $\mathrm{c}$ & $\mathrm{a}$ \\
& 0.468 & 0.414 & 0.521 & 0.305 & 0.240 \\
\hline \multirow{2}{*}{ Shele } & $\mathrm{ab}$ & $\mathrm{b}$ & $\mathrm{bc}$ & $\mathrm{c}$ & $\mathrm{a}$ \\
& 0.420 & 0.421 & 0.348 & 0.311 & 0.316 \\
\hline \multirow{2}{*}{ Dilan Hall } & $\mathrm{b}$ & $\mathrm{b}$ & $\mathrm{cd}$ & $\mathrm{ab}$ & $\mathrm{a}$ \\
& 0.490 & 0.386 & 0.266 & 0.448 & 0.220 \\
\hline \multirow{2}{*}{ Agri. College } & $\mathrm{c}$ & $\mathrm{c}$ & $\mathrm{d}$ & $\mathrm{d}$ & $\mathrm{b}$ \\
& 0.200 & 0.055 & 0.212 & 0.135 & 0.116 \\
\hline Mean & 0.422 & 0.370 & 0.355 & 0.346 & 0.228 \\
\hline
\end{tabular}

* Means with the same letters in each column are not significantly different at $5 \%$ level based on Duncan's multiple range tests.

The differences were insignificant among other locations, though the highest concentration was found in the Shele location. These values are smaller than those of studies [1 and 4]

Concentration of $\mathrm{Cd}$ in the vegetables was recorded in order of (chard plants $>$ celery plants $>$ leek plants $>$ onion plants $>$ radish plants).

The accumulation of $\mathrm{Cd}$ in all plants sampled from all locations was higher than the MPL in the vegetables recommended by the FAO and WHO, [8].

Nickel has been recently recognized as an essential nutrient element. It is usually present in plant tissue in a range of $0.05-5.0 \mathrm{mg} \mathrm{kg}^{-1} \mathrm{~d}$. wt. [14].

As shown in table 4, the lowest $\mathrm{Ni}$ content of chard plants was found in the Agri. College location (3.244 mg. $\mathrm{kg}^{-1} \mathrm{~d}$. wt), which was significantly different from all other locations with the exception of the Baro. location which differed insignificantly. The highest concentration was found in the Dilan Hall location (4.088 mg. kg-1 d. wt). These results were more than the value of $2.1 \mathrm{mg}^{-1} \mathrm{~kg}^{-1} \mathrm{~d}$. wt, reported [2 and 25] but they were less than value of $21.1 \mathrm{mg} . \mathrm{kg}^{-1} \mathrm{~d}$. wt, recorded by Mohamed et al, [16].

Concentration of $\mathrm{Ni}$ in the celery plants shows that the highest $\mathrm{Ni}$ content was observed in the Dilan Hall location (4.699 mg. $\mathrm{kg}^{-1} \mathrm{~d}$. wt), which was significantly different from other locations, while the lowest concentration was 
found in the Agri College location ( $3.7 \mathrm{mg} . \mathrm{Kg}^{-1} \mathrm{~d}$. wt). The results of $\mathrm{Ni}$ content in celery plants of this study were lower than the results $\left(15 \mathrm{mg} . \mathrm{Kg}^{-1} \mathrm{~d}\right.$. wt), obtained by Fytianos et al., [12], but higher than the results of Al-Ali, [2].

The lowest concentration of $\mathrm{Ni}$ can be seen in the Agri. College location (3.166 mg. $\left.\mathrm{kg}^{-1} \mathrm{~d} . \mathrm{wt}\right)$ and the highest Ni content $\left(3.566 \mathrm{mg} . \mathrm{kg}^{-1}\right)$ can be seen in leek plants sampled from the Baro. This difference may be due to the location of the Baro. It is situated in the manufacturing distinct of car maintenance in Dohuk. The results of Ni concentration in the leek plants were higher than 0.1 mg. $\mathrm{kg}^{-1} \mathrm{~d}$. wt reported [16], and smaller than results $12 \mathrm{mg}^{\mathrm{kg}}{ }^{-1} \mathrm{~d}$. wt [24], but near to $5 \mathrm{mg}$. $\mathrm{kg}^{-1} \mathrm{~d}$. wt [12].

The lowest concentration of $\mathrm{Ni}$ in onion plants was in the Agri. College location $\left(2.425 \mathrm{mg} . \mathrm{kg}^{-1} \mathrm{~d}\right.$. wt), and the highest concentration was found in the Azadi. H. location $\left(4.75 \mathrm{mg} . \mathrm{kg}^{-1} \mathrm{~d}\right.$. wt). These results were in good agreement with [13], less than [12], and more than [10].

$\mathrm{Ni}$ content in radish plants in the Agri. College location was less than other locations, and a higher concentration was found in the Shele location $(3.833 \mathrm{mg}$. $\mathrm{kg}^{-1} \mathrm{~d}$. wt). The results were close to the results of Gorbunov et al., [13]. Concentration of $\mathrm{Ni}$ in the vegetables was recorded in order of (celery plants $>$ chard plants $>$ onion plants $>$ leek plants $>$ radish plants). The accumulated concentration of $\mathrm{Ni}$ in all plants sampled from all locations was below the (MPL) of $\left(67.9 \mathrm{mg} . \mathrm{kg}^{-1} \mathrm{~d}\right.$. wt) in the vegetables [13].

Table 5 indicates that $\mathrm{Cu}$ concentrations in the chard plants range between (13.124 mg. kg ${ }^{-1}$ d. wt) in the Agri. College location and (15.455 mg. kg-1 d. wt) in the Baro. location. These concentrations were within the range of $\mathrm{Cu}$ concentration in vegetables in a study by [6], while these results were higher than [15].

Table 4: Nickel content (mg. $\mathrm{kg}^{-1} \mathrm{~d}$. wt.) of different plant types from different locations of Dohuk city.

\begin{tabular}{|l|c|c|c|c|c|}
\hline \multirow{2}{*}{ Locations } & \multicolumn{5}{|c|}{ Plant types } \\
\cline { 2 - 6 } & Chard & Celery & Leek & Onion & Radish \\
\hline \multirow{2}{*}{ Baro. } & $\mathrm{bc}^{*}$ & $\mathrm{~b}$ & $\mathrm{a}$ & $\mathrm{c}$ & $\mathrm{ab}$ \\
& 3.444 & 4.077 & 3.566 & 3.116 & 3.633 \\
\hline \multirow{2}{*}{ Azadi H. } & $\mathrm{ab}$ & $\mathrm{b}$ & $\mathrm{ab}$ & $\mathrm{a}$ & $\mathrm{ab}$ \\
& 3.855 & 3.777 & 3.544 & 4.750 & 3.566 \\
\hline \multirow{2}{*}{ Shele } & $\mathrm{a}$ & $\mathrm{b}$ & $\mathrm{abc}$ & $\mathrm{b}$ & $\mathrm{a}$ \\
& 4.066 & 4.122 & 3.533 & 3.716 & 3.833 \\
\hline \multirow{2}{*}{ Dilan Hall } & $\mathrm{a}$ & $\mathrm{a}$ & $\mathrm{bcd}$ & $\mathrm{a}$ & $\mathrm{bc}$ \\
& 4.088 & 4.699 & 3.453 & 4.293 & 2.766 \\
\hline \multirow{2}{*}{ Agri. College } & $\mathrm{c}$ & $\mathrm{a}$ & $\mathrm{d}$ & $\mathrm{d}$ & $\mathrm{c}$ \\
& 3.244 & 3.700 & 3.166 & 2.425 & 2.466 \\
\hline Mean & 3.739 & 4.075 & 3.452 & 3.660 & 3.253 \\
\hline
\end{tabular}

* Means with the same letters in each column are not significantly different at $5 \%$ level based on Duncan's multiple range tests. 
Table 5: Copper content (mg. $\mathrm{kg}^{-1} \mathrm{~d}$. wt.) of different plant types from different locations of Dohuk city.

\begin{tabular}{|l|c|c|c|c|c|}
\hline \multirow{2}{*}{ Locations } & \multicolumn{5}{|c|}{ Plant types } \\
\cline { 2 - 6 } Baro. & Chard & Celery & Leek & Onion & Radish \\
\hline \multirow{2}{*}{ Azadi H. } & $\mathrm{a}$ & $\mathrm{a}$ & $\mathrm{a}$ & $\mathrm{b}$ & $\mathrm{b}$ \\
& 15.455 & 16.888 & 14.411 & 9.833 & 6.633 \\
\hline \multirow{2}{*}{ Shele } & $\mathrm{abc}$ & $\mathrm{c}$ & $\mathrm{bcd}$ & $\mathrm{b}$ & $\mathrm{ab}$ \\
& 14.444 & 13.366 & 12.222 & 9.766 & 8.000 \\
\hline \multirow{2}{*}{ Dilan Hall } & $\mathrm{ab}$ & $\mathrm{b}$ & $\mathrm{ab}$ & $\mathrm{a}$ & $\mathrm{ab}$ \\
& 15.377 & 14.622 & 13.500 & 11.016 & 7.800 \\
\hline \multirow{2}{*}{ Agri. College } & $\mathrm{abc}$ & $\mathrm{cd}$ & $\mathrm{abc}$ & $\mathrm{b}$ & $\mathrm{a}$ \\
& 14.044 & 12.644 & 12.611 & 9.666 & 8.866 \\
\hline Mean & 13.124 & 12.044 & 11.364 & 10.466 & 8.500 \\
\hline
\end{tabular}

* Means with the same letters in each column are not significantly different at $5 \%$ level based on Duncan's multiple range tests.

The highest $\mathrm{Cu}$ concentration in the celery plants was observed in Baro. location (16.888 mg. kg ${ }^{-1} \mathrm{~d}$. wt), which was significantly different from other locations; even the lowest concentration was obtained from the Agri. College location $\left(12.044 \mathrm{mg} . \mathrm{kg}^{-1} \mathrm{~d}\right.$. wt) but it differed insignificantly from the Dilan Hall location. $\mathrm{Cu}$ content in the celery plants was more than [9]. Also it was smaller than [11]. The highest values of $\mathrm{Cu}$ content in leek plants were obtained from the Baro. location (14.411 mg. kg $\left.{ }^{-1} \mathrm{~d} . \mathrm{wt}\right)$ and the lowest concentration was found in the Agri. College location $\left(11.364 \mathrm{mg} . \mathrm{kg}^{-1} \mathrm{~d}\right.$. wt). Copper content in the leek plants was within the range of $1.56-21.9 \mathrm{mg}$. $\mathrm{kg}^{-1} \mathrm{~d}$. wt mentioned by Voutsa et al., [28], and more than $1.56 \mathrm{mg}$. $\mathrm{kg}^{-1} \mathrm{~d}$. wt, the results of Mohamad et al., [16].

The highest $\mathrm{Cu}$ content in the onion plants was observed in the Shele location $\left(11.016 \mathrm{mg} . \mathrm{kg}^{-1} \mathrm{~d}\right.$. wt) which was not significantly different from the Agri. College location. The lowest $\mathrm{Cu}$ content was obtained from the Dilan Hall location $\left(9.666 \mathrm{mg} . \mathrm{kg}^{-1} \mathrm{~d}\right.$. wt). These results were much higher than $(0.09 \mathrm{mg}$. $\mathrm{kg}^{-1} \mathrm{~d}$. wt) reported by Parveen et al., [17] while they were less than $(49.0 \mathrm{mg}$. $\mathrm{kg}^{-1}$ d. wt) [10].

The lowest $\mathrm{Cu}$ content $\left(6.633 \mathrm{mg} . \mathrm{kg}^{-1} \mathrm{~d}\right.$. wt) of radish plants was in the Baro. and the highest $\mathrm{Cu}$ concentration $\left(8.866 \mathrm{mg} . \mathrm{kg}^{-1} \mathrm{~d}\right.$. wt) was obtained from radish plants cultivated in the Dilan Hall location. The mean $\mathrm{Cu}$ content in the radish plants of the present study was $\left(7.9 \mathrm{mg} . \mathrm{kg}^{-1} \mathrm{~d}\right.$. wt) which was less than $21.2 \mathrm{mg}$. $\mathrm{kg}^{-1} \mathrm{~d}$. wt that recorded by Ansari et al. [4]. These results were also within the range (3.1-15.4 mg. $\mathrm{kg}^{-1} \mathrm{~d}$. wt) observed [24].

Concentration of $\mathrm{Cu}$ in the vegetables was recorded in order of (chard plants $>$ celery plants $>$ onion plants $>$ leek plants $>$ radish). The accumulated concentration of $\mathrm{Cu}$ in all plants from all locations was below the (MPL) (73.3 $\mathrm{mg} . \mathrm{kg}^{-1} \mathrm{~d}$. wt) in the vegetables proposed by Weight, [29]. 
Same trend of results (water) were not appeared by determination the heavy metals in different vegetables taken from same location with rivulet. This means that the sources of heavy metals may be other than water used for irrigation, such as soil [18] or deposition from atmospheric.

\section{References}

[1] Adhikari, S; Mitra, A; Gupta, S. K. and Banerjee, S. K., Pollutant metal contents of vegetables irrigated with sewage water. J. of the Ind. Soci. of Soil Sci., 46 (1): 153-155,1998.

[2] Al-Ali, F. A. M., Effect of the polluted water on plant growth and its content of some microelements and heavy metals. Ph. D Thesis College of Science, University of Mosul, Iraq. 1996.

[3] Al-Barware, M.R.A., Evaluation of the quality of irrigation Water sources of celery plant Apium graveulense in Mosul city and the resultant pollution, M.Sc. Theses. College of Science, University of Mosul, Iraq, 2004.

[4] Ansari, T. P; Kazi, T. G. and Laboudigue, A. and Lecomte, P., Bioavailability to vegetables of trace and toxic elements from Agricultural soil and sludge amended soil. Hamdard Medic, 42 (1): 63-73, 1999.

[5] APHA. (American public Health Association) (1989). Standard methods for the examination of water and wastewater analysis, American public health association, Washington, Dc, USA.

[6] Bahemuka, T. E. and Mubofu, E. B., Heavy metals in edible Green vegetables grown along the sites of the Sinza and Msimbazi rivers in Dar as Salaam, Tanzania. Food chemis., 66:63-66,1999.

[7] Besamiatnov, G. P. and Krotov, Yu. A. (1985). Maximum allowable concentration of chemical substance in the environment; L. Kimia in Russia, 528 pp.

[8] Codex Alimentarius Commission. Contaminants, joint FAO / WHO food standards program, Codex Alimenturius, vol. XVIT (1st edition). 1984.

[9] Czuba, M. and Hutchinson, T.C., Copper and lead levels in crops and soils of the Holland marsh Area-Ontario. J. Environ. Qual; 9:566-575, 1980.

[10] El-Naim, M. A; El-Houssini, M; and Naeem, M.H., Safety use of sewage sludge as soil conditioner. J. of Environ. Sci. and Health, A39 (2): 435 444, 2004.

[11] Fahim, F. A; Abdollah, A. M. A. and Abdel Razik, T. A. M. Flow and accumulation of pollutants in an agro-industrial ecosystem. J. of Afric. Earth Sci., 20 (3-4): 295-301, 1995.

[12] Fytianos, K; Katsianis, G; Trintafyllow, P. and Zachariadis, G. Accumulation of heavy metals in vegetables grown in an industrial area in relation to soil. Bull. Environ Contam. Toxicol; 67: 423-430. 2001.

[13] Gorbounov, A. V; Frontasyeva, M. V; Kistanov, A. A; Lyapunov, S. M; Okina, O. and Ramadan, A. B., Heavy and toxic metals in staple foodstuffs and agriproduct from contaminated soils. J. Environ. Sci. Health, B38: 181-192, 2003. 
[14] Hopkins, W. G., Introduction to plant physiology, 2nd Edition. John Wiley \& Sons, Inc, USA, 1999.

[15] Itanna, F, Metals in leafy vegetables grown in Addis Ababa and toxicological implications. Ethiop. J. Health Dev; 16 (3): 295-302, 2002.

[16] Mohamed, A. E; Rashed, M. N. and Mofty, A., Assessment of essential and toxic elements in some kinds of vegetables. Ecotoxicolo. and Environ. Safety, 55: 251-260. 2003.

[17] Parveen, Z; Khuhro, N.I. and Rafiq, N. Market basket survey for lead, cadmium, copper, chromium, nickel, and zinc in fruits and vegetables. Bull. Environ. Contam. Toxicol. , 71:1260-1264, 2003.

[18] Pileggard, K; Rasmussen, L; and Gydesen, H., Atmospheric Background deposition of heavy metals in Denmark monitored by Epiphytic Cryptogams. J. of Applied Ecol., 16:843-853, 1979.

[19] Preer, J. R. and Sekhon, H. S., Factor affecting heavy metal content of garden vegetables. Environ. Pollut., 94: 385-335, 1980.

[20] Saghatelyan, A. K; Arevshatyan, S. H; and Nalbandyan, M. A., Heavy metals in system "water-silt-plant" within the limits of Yerevan. Electronic J. of Sci., 1(2): 20-26, 2004.

[21] Salunkhe, D. K., Handboo of vegetable science and technology: production, composition, storage, and processing. New York Marcel Dekker, Inc, 1998.

[22] Sulaivany, R. O. and Al-Mezori, H. A., Heavy metals concentration in soil and wastewater used for irrigation in Dohuk city. Kurdistan 1st conference of biological sciences, University of Dohuk. 2-4 may, 2006.

[23] Tandon, H., Methods of analysis of soils, plants, water and fertilizers. Fertilizers Development and Consultation, New Delhi India, pp.144. 1999.

[24] Tokalioğlu, S. and Kartal, S., Relationship between vegetable metal and Soil-Extractable metal contents by the BCR sequential extraction procedure: Chemometrical interpretation of the data. Intern. J. Environ. Anal. Chem; 83:935-952, 2003.

[25] Ursínyová, M. and Hladíková, V., Essential elements in Environmental samples from selected regions in Slovakia. Bull. Environ. Contam. Toxicol; 62:409-415, 1999.

[26] Védry, B; Gousailles, M; Affholder, M; Lefaux, A. and Bontoux, J., of Paris sewage farms history. Water Sci. and Technol., 43:101- 107, 2001.

[27] Voegborlo, R. B., Elements in raw leafy vegetables grown in Wadi AlShati (Central Sahara). Food Chemist., 48: 317-319,1993.

[28] Voutsa, D; Grimanis, A. and Samara, C., Trace elements in vegetables grown in an industrial area in relation to soil and air particulate matter. Environ. Pollut., 94:328-225, 1996.

[29] Weight, N. G., Metal loads of food of vegetables origin including mushrooms. In: Merian, E, ed. Metals and Their Compounds in the Environment: Occurrence, Analysis, and Biological Relevance. Weinheim: VCGH, 458-468, 1991. Sited from: Itanna, F., Metals in Leafy Vegetables Grown in Addis and Toxicological Impations. Ethiop. J. Health Dev; 16(3): 295-302, 2002. 